\title{
MODEL KAJIAN KOMPETENSI PEGAWAI, EFEKTIVITAS PERALATAN GROUND SUPPORT EQUIPMENT DAN KEPUASAN KERJA TERHADAP KUALITAS PELAYANAN PT. JASA ANGKASA SEMESTA
}

\author{
* Lira Agusinta ${ }^{1}$, Aji Endra Nugroho ${ }^{2}$, Peppy Fachrial ${ }^{3}$, Ryan Firdiansyah Suryawan ${ }^{4}$ \\ 1,2,3 Institut Transportasi dan Logistik Trisakti, Jakarta, Indonesia \\ ${ }^{4}$ Sekolah Tinggi Penerbangan Aviasi, Jakarta, Indonesia
}

*Email Korespondensi:

lir4agusinta@gmail.com

\section{ARTIKEL INFORMASI}

Diterima:

25 Juni 2021

Direvisi:

12 Juli 2021

Dipublikasi:

22 Juli 2021

\begin{abstract}
ABSTRAK
Tujuan Penelitian ini adalah Untuk mengetahui adanya pengaruh tiga variabel kompetensi pegawai, efektivitas peralatan Ground Support Equipment (Peralatan Penunjang Pelayanan Darat Pesawat Udara) dan kepuasan kerja terhadap kepuasan kerja pada PT. Jasa Angkasa Semesta di Bandar Udara Soekarno-Hatta Jakarta, Metode penelitian ; metode deskriptif dengan pendekatan kuantitatif. Hasil dari penelitian ini secara lagsung dan tidak langsung, Untuk pengaruh langsung antara variabel kompetensi pegawai, efektivitas peralatan GSE dan kepuasan kerja terhadap kualitas pelayanan diatas dapat disimpulkan bahwa kualitas pelayanan Bagian Operasional PT. Jasa Angkasa Semesta di Bandar Udara SoekarnoHatta Jakarta, memiliki urutan yaitu kepuasan kerja sebesar 0.489 atau $48.9 \%$, kompetensi pegawai 0.262 atau $26.2 \%$ dan efektivitas peralatan GSES sebesar 0.262 atau $26.2 \%$, dan pengaruh tidak langsung dapat disimpulkan bahwa kompetensi pegawai memberikan kontribusi terhadap kepuasan kerja disebabkan oleh kemampuan-kemampuan yang dimiliki pegawai dalam menyelesaikan pekerjaan karena mampu memenuhi target dan tujuan perusahaan yang telah ditentukan kepuasan tersendiri oleh para pegawai.
\end{abstract}

Kata Kunci: Kompetensi, Ground Support Equipment, Kepuasan Kerja

\section{PENDAHULUAN}

Sumber daya manusia adalah merupakan salah satu sumber daya organisasi yang memiliki peran penting dalam mencapai tujuannya. Setiap organisasi dikelola manusia. Tanpa manusia, organisasi itu tidak ada. Tantangan dan peluang dalam menciptakan dan mengelola organisasi kerap kali bersumber dari masalahmasalah yang ada kaitannya dengan manusia. Oleh karena itu mengelola sumber daya manusia (SDM) adalah sumber daya paling vital merupakan aktivitas sentral dan strategis. Banyak faktor yang menyebabkan sumber daya manusia memiliki kinerja unggul, sehingga mampu mendorong keberhasilan organisasi, salah satunya adalah kompetensi.

Kompetensi dari pegawai atau karyawan dapat diketahui dari pendidikan dan pelatihan yang pernah diterima, keahlian dan pengalaman. Permasalahan yang terjadi di lapangan adalah terkadang kompetensi dari 
seorang kru saja tidaklah cukup untuk menjamin kinerja pegawai, perlu adanya sebuah kerjasama antar beberapa personel sehingga menghasilkan sinergi untuk melaksanakan kinerja dalam memberikan pelayanan darat pesawat udara agar mampu meningkatkan kualitas pelayanan secara efektif dan efisien waktu, terutama peralatan Ground Support Equipment (GSE). Persaingan yang ada tidak hanya dari segi mutu dan jumlah tetapi juga dalam hal layanan. Memperhatikan layanan yang semakin menonjol maka tidaklah heran apabila masalah layanan mendapat perhatian besar yang sering kali dibicarakan, baik oleh masyarakat maupun manajemen itu sendiri baik secara khusus maupun dalam kaitannya dengan kegiatan organisasi, begitu juga jasa pelayanan jasa transportasi udara, permintaan terhadap industri jasa penerbangan untuk angkutan penumpang, barang dan pos secara global menunjukkan grafik peningkatan dari tahun ke tahun.

Dalam beberapa tahun terakhir, pengguna jasa transportasi udara di Indonesia mengalami pertumbuhan yang meningkat, tercatat menurut data Kementerian Perhubungan, pada tahun 2015 jumlah penumpang penerbangan domestik di Indonesia telah mengalami pertumbuhan sebesar 168,8 juta, meningkat 2,7\% dibandingkan pada tahun 2014. Sementara itu, untuk perjalanan penumpang internasional mencapai 34,33 juta di tahun 2015 meningkat 2,1\% dibandingkan pada tahun 2014. Jumlah di atas diperkirakan akan terus mengalami peningkatan sampai bulan Mei tahun 2019.

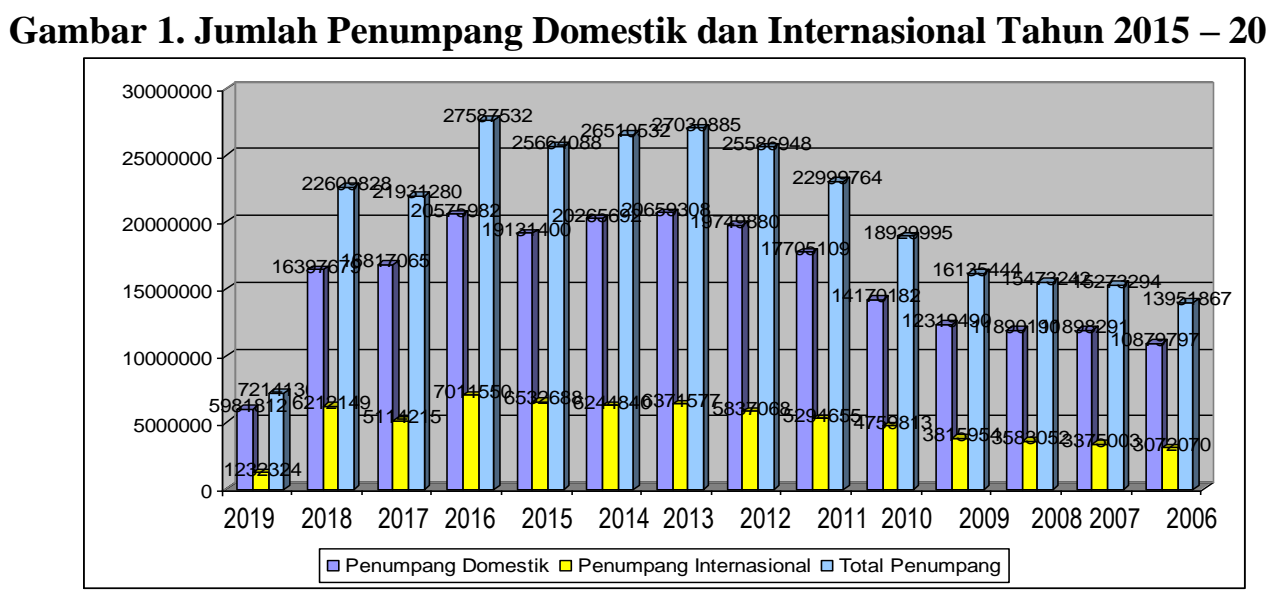

Sumber: Diolah dari BPS,2019 (www.bps.go.id, diakses 18 Juni 2019 pukul. 20.30 WIB). Catatan: Data Tahun 2019 sampai bulan Mei 2019

Sejalan dengan pertumbuhan penumpang pesawat udara di Indonesia tersebut, perkembangan pengguna Bandara Soekarno-Hatta sebagai bandara utama di Indonesia juga meningkat, data berikut menunjukkan penumpang yang berangkat dari Bandara Soekarno-Hatta sebagaimana tertera dalam Tabel 1. berikut.

Tabel 1. Penumpang yang Berangkat Dari Bandara Soekarno-Hatta Tahun 2006-2019

\begin{tabular}{ccccc}
\hline Tahun & $\begin{array}{c}\text { Penumpang } \\
\text { Domestik }\end{array}$ & $\begin{array}{c}\text { Penumpang } \\
\text { Internasional }\end{array}$ & $\begin{array}{c}\text { Total } \\
\text { Penumpang }\end{array}$ & Pertumbuhan \\
\hline 2019 & 5.981 .812 & 1.232 .324 & 7.214 .136 & $-213 \%$ \\
\hline 2018 & 16.397 .679 & 6.212 .149 & 22.609 .828 & $3 \%$ \\
\hline 2017 & 16.817 .065 & 5.114 .215 & 21.931 .280 & $-26 \%$ \\
\hline 2016 & 20.575 .982 & 7.011 .550 & 27.587 .532 & $4 \%$ \\
\hline 2015 & 19.131 .400 & 6.532 .688 & 25.664 .088 & $2 \%$ \\
\hline 2014 & 20.265 .692 & 6.244 .840 & 26.510 .532 & $-2 \%$ \\
\hline 2013 & 20.659 .308 & 6.371 .577 & 27.030 .885 & $6 \%$ \\
\hline 2012 & 19.749 .880 & 5.837 .068 & 25.586 .948 & $11 \%$ \\
\hline 2011 & 17.705 .109 & 5.294 .655 & 22.999 .764 & $21 \%$ \\
\hline 2010 & 14.170 .182 & 4.759 .813 & 18.929 .995 & $17 \%$ \\
\hline
\end{tabular}

Sumber: Diolah dari BPS,2019 (www.bps.go.id, diakses 18 Juni 2019 pukul. 20.30 WIB). Catatan: Data Tahun 2019 sampai bulan Mei 2019

Berdasarkan tabel diatas dapat diketahui jumlah penumpang baik penumpang domestik dan jumlah 
penumpang internasional dalam kurun waktu 10 tahun yang dimulai dari tahun 2010 sampai tahun 2019 (sampai bulan Mei) yang berangkat dari Bandar Udara Soakernao-Hatta Jakarta jumlah tertinggi pada tahun 2016 dengan total penumpang 27.587 .532 naik perkembangan sebesar $4 \%$ dari tahun sebelumnya pada tahun 2015 yang berjumlah 25.664.088 yang perkembangan 25 berarti antara tahun 2015 ke tahun 2016 naik 2\%, dan terendah pada tahun 2019 yang berjumlah 7.214.136 sampai bulan Mei yang sebesar 7.214.136 atau turun 21.3\% dilihat dari perkembanganya per bulan pada tahun 2019 perkembanganya sangat lambat, banyak faktor yang mempengaruhi perkembangan jumlah penumpang baik penumpang domestic dan internasional salah satunya harga tiket yang sangat mahal dimulai pada awal bulan dari tahun 2019.

Semakin berkembangnya bidang usaha Jasa Penanganan Pelayanan Darat (Ground handling Services), seiring dengan berkembangnya industri jasa penerbangan serta persaingan yang sangat ketat dalam dunia jasa penerbangan baik dalam lingkup nasional maupun internasional. Kondisi tersebut menyebabkan adanya tuntutan terhadap kualitas kinerja jasa penanganan pelayanan darat yang andal, berkualitas, dan profesional. Pelayanan jasa penerbangan meliputi pelayanan sebelum penerbangan (pre-flight services), pelayanan selama penerbangan (in-flight services), dan pelayanan sesudah penerbangan (post-flight services). Salah satu bentuk pelayanan jasa penerbangan tersebut adalah jasa penanganan pelayanan darat (ground handling services) yang diantaranya meliputi pelayanan dan penanganan terhadap penumpang, bagasi, kargo, pos, dan pesawat. Pelayanan ini tentunya diberikan pada tahap sebelum dan sesudah penerbangan (pre-flight dan post-flight).

PT. Jasa Angkasa Semesta (JAS) adalah perusahaan penyedia jasa pelayanan Tata Operasi Darat atau Ground Handling di Bandar Udara yang berpusat di Jakarta, dibentuk, sebagai pelaksana ground handling dan pendukung kegiatan penerbangan di kawasan bandara baik penerbangan domestik maupun internasional. Guna meningkatkan kualitas pelayanan terbaik penyediaan jasa ground handling bagi para pelanggannya, perusahaan jasa ground handling PT. Jasa Angkasa Semesta juga dihadapkan pada beberapa masalah yang terkait dengan kegiatan operasionalnya, terusama Sumber Daya Manusia (SDM), masalah yang sering terjadi pada sebuah organisasi ataupun perusahaan salah satunya adalah sumber daya manusia dalam hal ini tenaga kerja atau pegawai berperan dalam perkembangan perusahaan, sehingga pegawai diberi pengawasan atau perhatian perusahaan terurama kepuasan kerja dengan memberi motivasi agar karyawan dan bekerja secara efektif, efisieian maupun professional yang berpedoman pada standar operaional perusahaan. Kepuasan kerja karyawan tersebut meliputi kepuasan terhadap beban kerja, kompensasi, promosi, pengawasan (supervisor), dan rekan kerja. Hal ini sesuai dengan pendapat Robbins dan Judge (2011) yang menyatakan bahwa indikator kepuasan kerja dapat dilihat dari: kepuasan terhadap pekerjaan itu sendiri, kepuasan terhadap imbalan dari pekerjaan itu, kesempatan promosi, kepuasan terhadap supervisi dari atasan, dan kepuasan terhadap rekan kerja.

Di dalam pelayanan diperlukan perlengkapan fasilitas peralatan penunjang pelayanan darat pesawat udara, berbagai macam model kendaraan/peralatan yang beroperasi di area apron (parkir) pesawat udara. nah semua peralatan ini memiliki fungsi tersendiri yang dibutuhkan sebagai peralatan penunjang pelayanan darat pesawat udara yang juga biasa disebut Peralatan Ground Support Equipment (GSE). Permasalahan yang paling sering dihadapi oleh divisi layanan yang terdiri dari bagian perawatan, customer service dan documentation staff. Bandara Soekarno-Hatta saat ini tidak hanya sekedar bandara, tetapi juga area yang dapat menumbuhkan kreasi dalam industri teknologi digital. Berbagai fasilitas berteknologi canggih dan modern ada di bandara ini, begitu juga perusahaan ground handling ikut mengembangkan fasilitas pelayanan kepada penumpang. Komitmen itu diwujudkan oleh PT. Jasa Angkasa Semesta dalam upaya meningkatkan dan fasilitas peralatan penunjang pelayanan darat pesawat udara agar mampu melayani secara efektif dan efisien waktu, terutama peralatan Ground Support Equipment (GSE). penunjang pelayanan darat dapat digunakan secara terampil.

Terjadinya masalah di tiga bagian berpotensi menyebabkan munculnya rasa ketidakpuasan terhadap pelayanan yang diberikan perusahaan ground handling. Sebagai contoh, dalam hal kemampuan (ability), bila terjadi kesalahan input data atau penyesuaian penjadwalan perawatan. Akibatnya, bisa berdampak muncul biaya dan waktu tambahan untuk perbaikan. Dari sisi sikap (attitude), kerap terjadi penundaan pemrosesan data, hingga muncul reminder dari pelanggan, memperlihatkan emosi ketika melayani pelanggan, semisal ketika pelanggan mengeluh atau menyampaikan banyak permintaan terkait dokumen dan lain-lain. Terkait soal penampilan (appearance), karyawan seringkali tidak tampil dalam pakaian yang sopan, serasi dan kurang senyum dalam melayani pelanggan. Unsur perhatian (attention), antara lain tampak ketika karyawan mengabaikan keluhan dan permintaan-permintaan tambahan dari pelanggan. Aspek minimumnya tanggung jawab (accountability) tampak dalam sikap saling lempar bila terjadi kesalahan. 
PT. Jasa Angkasa Semesta sebagai ground handling memilki jenis-jenis pelayanan salah satunya adalah ramp handling yang merupakan unit untuk memberikan pelayanan di bagian Apron (Apron Service) yang meliputi pelayanan loading dan unloading, cargo dan mail di pesawat berdasarkan load instruction, mencatat stock terhadap pemeliharaan unit load service (ULD) milik airlines, tujuannya yang ingin dicapai dengan adanya ramp handling ini diantaranya safety (keselamatan), reguler (teratur), OTP (on Time Performance) Karena begitu banyaknya peralatan GSE di PT. Jasa Angkasa Semesta maka dibutuhkan pengontrolan dan perawatan yang baik agar peralatan dapat berfungsi optimal sehingga mendukung kegiatan operasional ground handling, diperlukan ketrampilan dan kemampuan agar efektivitas perlatan GSE mampu beroperasi secara efektif dan efisien waktu. Namun ternyata masih banyak kendala yang terjadi pada peralatan $G S E$, kendala tersebut berupa kegiatan schedule maintenance. Berdasarkan audit yang sering dilakukan oleh semua airlines yang di handle oleh PT. Jasa Angkasa Semesta, data Inventory maintenance sangat mempunyai peranan penting guna menjawab setiap audit yang dilakukan oleh airlines.

Hasil observasi dan pengamatan di lapangan bahwa tidak semua petugas memahami tentang fungsi dari peralatan penunjang pelayanan darat pesawat udara, fungsi peralatan penunjang menjadikan pegawai salah memilih alat untuk dipergunakan, kurangnya jumlah dari kehandalan peralatan Ground Support Equipment (peralatan penunjang pelayanan darat pesawat udara) yang handal, peralatan yang sudah usang dan tua, belum mempunyai sertifikasi dan kelaikan operasi dari regulator. Beberapa faktor yang berpengaruh uang mempengaruhi kinerja pegawai perusahaan jasa penanganan pelayanan darat diantaranya adalah kualitas meliputi pendidikan dan pelatihan, profesionalises, sarana dan kehandalan Ground Support Equipment yang meliputi fasilitas peralatan penunjang kerja pegawai.

Identifikasi Masalah, dilihat dari latar belakang masalah di atas, maka diidentifikasi masalah sebagai berikut; 1) Belum terukurnya kompetensi antar pegawai, 2) Kompetensi antar pegawai belum berjalan dengan baik, 3) Belum terlaksananya pengawasan perusahaan pada kepuasan kerja pegawai terutama promosi kenaikan jabatan dan tunjangan maupun bonus, 4) Lemahnya pengawasan jajaran pimpinan PT. Jasa Angkasa Semesta dalam meningkatkan pelayanan perusahaan, 5) Terbatasnya fasilitas peralatan penunjang pelayanan darat pesawat udara PT. Jasa Angkasa Semesta, 5) Belum terumuskannya indikator PT. Jasa Angkasa Semesta terhadap pelayanan yang baik, 5) Lemahnya kreativitas pegawai sehinggan peralatan GSE belum dapat digunakan secara efektif.

Tujuan Penelitian, penelitian ini bertujuan untuk ; 1) Untuk mengetahui pengaruh kompetensi pegawai, efektivitas peralatan Ground Support Equipment (Peralatan Penunjang Pelayanan Darat Pesawat Udara) dan kepuasan kerja terhadap kepuasan kerja pada PT. Jasa Angkasa Semesta di Bandar Udara Soekarno-Hatta Jakarta?, 2) Untuk mengetahui pengaruh kompetensi pegawai dan efektivitas peralatan Ground Support Equipment (Peralatan Penunjang Pelayanan Darat Pesawat Udara) terhadap kepuasan kerja pada PT. Jasa Angkasa Semesta di Bandar Udara Soekarno-Hatta Jakarta?, 3) Untuk mengetahui pengaruh antara kepuasan kerja terhadap kualitas pelayanan pada PT. Jasa Angkasa Semesta di Bandar Udara Soekarno-Hatta Jakarta, 4) Untuk mengetahui pengaruh antara Kepuasan Kerja terhadap Kualitas Pelayanan, 5) Untuk mengetahui pengaruh Efektivitas Peralatan Ground Support Equipment terhadap Kualitas Pelayanan Melalui Kepuasan Kerja.

\section{KAJIAN PUSTAKA}

Kompetensi menurut Wibowo (2016) adalah suatu kemampuan untuk melaksanakan atau melakukan suatu pekerjaan atau tugas yang dilandasi atas keterampilan dan pengetahuan serta didukung oleh sikap kerja yang dituntut oleh pekerjaan tersebut. Menurut Spencer dan Spencer dalam Wibowo (2016) menyatakan bahwa kompetensi merupakan landasan dasar karakteristik orang dan mengindikasikan cara berperilaku atau berpikir, menyamakan situasi, dan mendukung untuk periode waktu cukup lama.

Sedangkan menurut Amstrong (dalam Dharma, 2016) kompetensi mengacu kepada dimensi perilaku dari sebuah peran atau perilaku yang diperlukan seseorang untuk dapat melaksanakan pekerjaannya secara memuaskan. Moeheriono (2017) mengemukakan bahwa kompetensi adalah sebuah karakteristik dasar seseorang yang mengidentifikasi cara berpikir, bersikap, dan bertindak serta menarik kesimpulan yang dapat dilakukan dan dipertahankan oleh seseorang pada waktu periode tertentu. 
Sedangkan menurut Mc Clelland dalam Veithzal Rivai dan Ella Jauvani Sagala (2015) kompetensi (competency) sebagai karakteristik yang mendasar yang dimiliki seseorang yang berpengaruh langsung terhadap, atau dapat memprediksikan, kinerja yang sangat baik. Dari beberapa pendapat ahli yang telah dibahas maka dapat disimpulkan bahwa kompetensi merupakan karakteristik dasar yang dimiliki individu atau seorang pegawai yaitu kemampuan dalam melaksanakan suatu pekerjaan/tugas yang dilandasi dengan kemampuan, keterampilan, pengetahuan, serta cara berpikir yang didukung oleh sikap kerja dalam melaksanakan dan menyelesaikan suatu pekerjaan.

Menurut Ravianto dalam Masruri (2017), efektivitas adalah seberapa baik pekerjaan yang dilakukan, sejauhmana orang menghasilkan keluaran sesuai dengan yang diharapkan. Ini berarti bahwa apabila suatu pekerjaan dapat diselesaikan denganperencanaan, baik dalam waktu, biaya mau pun mutunya, maka dapat dikatakan efektif. Bungkaes (2013) efektivitas adalah hubungan antara output dan tujuan, dalam artian efektivitas merupakan ukuran seberapa jauhtingkat output, kebijakan dan prosedur dari organisasi mencapaitujuan yang ditetapkan. Bila ditelusuri efektivitas berasal dari kata dasar efektif yang artinya : (1). Ada efeknya (pengaruhnya, akibatnya, kesannya)seperti: manjur; mujarab; mempan; (2). Penggunaan metode/cara, sarana/alat dalam melaksanakan aktivitas sehinggaberhasil guna (mencapai hasil yang optimal).”

T. Hani Handoko (2015) menyatakan pendapatnya tentang efektivitas merupakan kemampuan untuk memilih tujuan yang tepat atau peralatan yang tepat untuk pencapaian tujuan yang telah ditetapkan. Selanjutnya Steers (2015) mengemukakan bahwa: "Efektivitas adalah jangkauan usaha suatu program sebagai suatu sistem dengan sumber daya dan sarana tertentu untuk memenuhi tujuan dan sasarannya tanpa melumpuhkan cara dan sumber daya itu serta tanpa memberi tekanan yang tidak wajar terhadap pelaksanaannya".

Menurut Gibson et.al (2016), efektivitas adalah penilaian yang dibuat sehubungan dengan prestasi individu, kelompok, dan organisasi. Makin dekat prestasi mereka terhadap prestasi yang diharapkan (standar), maka makin lebih efektif dalam menilai mereka. Berdasarkan uraian-uraian tersebut di atas maka dapat diartikan, bahwa efektivitas kerja adalah suatu usaha untuk menyelesaikan suatu pekerjaan tepat pada waktunya sesuai dengan yang telah ditentukan dan hasilnya sesuai standar yang diinginkan serta dalam pelaksanaannya memperhatikan bagaimana cara menyelesaikan dan jumlah biaya yang dikeluarkan suatu organisasi / instansi.

Ground handling berasal dari kata Ground dan Handling. Ground artinya darat atau di darat, yang dalam hal ini di banda udara (airport). Handling berasal dari kata dasar hand atau handle yang artinya tangan atau tangani. To handle berarti menangani, melakukan suatu pekerjaan tertentu dengan penuh kesadaran. Handling berarti penanganan atau pelayanan (services or to services). Sehingga pada banyak kesempatan, kita sering menjumpai pemakaian kata Ground Services (pelayanan darat atau pelayanan di airport).

Kata Ground handling mengandung pengertian yaitu suatu aktivitas perusahaan penerbangan yang berkaitan dengan penanganan atau pelayanan terhadap para penumpang berikut bagasinya, kargo, pos, peralatan pembantu pergerakan pesawat di darat dan pesawat terbang itu sendiri selama berada di Bandar udara, baik untuk keberangkatan maupun untuk kedatangan. Secara sederhana ground handling atau tata operasi darat adalah pengetahuan dan keterampilan tentang penanganan pesawat di Apron, penanganan penumpang dan bagasinya di Terminal, dan penanganan kargo dan pos di Cargo area.

Ruang lingkup dan batasan pekerjaan ground handling yaitu pada tahap Pre Flight dan Post Flight, yaitu penanganan penumpang dan pesawat selama berada di bandar udara. Secara teknis operasional, aktivitas ground handling dimulai pada saat pesawat taxi (parking stand), mesin pesawat sudah dimatikan, roda pesawat sudah diganjal, (block on), dan pintu pesawat sudah dibuka (open the door) dan para penumpang sudah dipersilakan untuk turun atau keluar dari pesawat, maka pada saat itu para staf darat sudah memiliki kewenangan untuk mengambil alih pekerjaan dari Pilot In Command (PIC) beserta crewnya. Fase ini kita menamakan Arrival Handling (pelayanan kedatangan penumpang). Sebaliknya, kegiatan atau pekerjaan orangorang darat berakhir ketika pesawat siap-siap untuk tinggal landas, yaitu saat pintu pesawat ditutup, mesin dihidupkan dan ganjal roda pesawat sudah dilepas (block off). Tanggungjawab pada fase ini (In Flight) berada di tangan Pilot In Command beserta para awak kabinnya. Fase ini kita kenal dengan istilah Departure Handling. Obyek yang ditangani oleh ground staff pada intinya meliputi penumpang (pax), barang bawaan penumpang (baggage), barang kiriman (cargo), benda-benda pos (mail), ramp dan aircraft. Ruang lingkup atau obyek kegiatan pada intinya harus mengacu kepada aturan yang ditetapkan oleh IATA Airport Handling Manual, 810 Annex yang menetapkan sebanyak 14 section pelayanan standar atau 14 item kegiatan. 
Pada hakekatnya ada tiga komponen utama penyelenggaraan bisnis penerbangan dapat berjalan, khususnya ground handling. Ketiga komponen tersebut adalah perusahaan penerbangan (airlines), berikut sarana angkutnya berupa pesawat terbang (aircraft), bandar udara (airport) dan konsumen (dalam hal ini passangers dan shipper). Ketiga komponen utama inipun secara sendiri-sendiri memiliki keterkaitan dengan unit-sub unit lainnya yang memiliki peran tidak kecil. Sederhananya, kegiatan atau pekerjaan ground handling dapat terlaksana kalau ada perusahaan penerbangan, ada pesawat ada bandara dan ada calon penumpangnya. Tanpa itu semua maka kegiatan ground handling tidak akan ada. Dua komponen yang sangat terkait secara langsung adalah perusahaan penerbangan dan bandar udara. Secara umum, sebuah bandar udara harus memiliki sarana dan prasarana minimal, yaitu landasan pacu pesawat yang memenuhi syarat (runway), menara pengontrol lalu lintas udara (air traffic control), dan gedung terminal (terminal building). Berdasarkan area, bandara dapat dikelompokan menjadi dua bagian, ialah sisi darat (land side) dan sisi udara (air side). Khusus untuk gedung terminal, bandar udara dapat dibagi kedalam tiga wilayah yang disebut Public Area, Restricted Area dan Non Public Area.

International Air Transport Association (Asosiasi Pengangkutan Udara Internasional; disingkat IATA) adalah sebuah organisasi perdagangan internasional yang terdiri dari maskapai-maskapai penerbangan. IATA bermarkas di Montreal, Kanada. Maskapai-maskapai penerbangan anggotanya diberikan kelonggaran khusus sehingga dapat mengkonsultasikan harga antara sesama anggota melalui organisasi ini. IATA juga bertugas menjalankan peraturan dalam pengiriman barang-barang berbahaya dan menerbitkan panduan Peraturan Barang-barang Berbahaya IATA (IATA Dangerous Goods Regulations). Selain itu ada juga IATA Airport Handling Manual, 810 Annex A, Tahun 2004 yang menetapkan sebanyak 8 section pelayanan standar, sebagai berikut; Section 1 : Representtion, Administration \& Supervision, Section 2 : $\quad$ Passenger Services, Section 3 : $\quad$ Ramp Services, Section 4 : Load Control, Communication \& Flight Operations, Section 5 : Cargo \& Mail Services, Section 6 : $\quad$ Support Services, Section 7: $\quad$ Security, Section 8 : Aircraft Maintenance.

Ground Support Equipment biasa ditemukan di suatu Bandar Udara, terkadang berada di jalur area pelayanan terminal. Peralatan ini digunakan untuk melayani pesawat terbang sebelum keberangkatan maupun setelah tiba di bandara, dinamakan Ground Support Equipment karena peralatan ground handling ini dapat mendukung operasi pesawat ketika berada di darat. Adapun fungsi umum dari peralatan ini meliputi ground power operations, aircraft mobility, dan loading operations (penumpang dan barang). efektivitas peralatan penunjang pelayanan darat pesawat udara $(G S E)$ adalah kemampuan untuk memilih tujuan yang tepat atau penggunaan metode/cara, sarana/alat dalam melaksanakan aktivitas sehingga berhasil guna (mencapai hasil yang optimal) yang tepat untuk pencapaian tujuan yang telah ditetapkan.

Menurut Luthans (2015), kepuasan kerja adalah suatu keadaan emosi seseorang yang positif maupun menyenangkan yang dihasilkan dalam suatu pekerjaan atau pengalaman kerja. Menurut Siagian (2017), kepuasan kerja merupakan suatu cara pandang seseorang baik yang bersifat positif maupun yang bersifat negatif tentang pekerjannya. Menurut Robbins (2017) menyatakan kepuasan kerja adalah sikap umum individu terhadap pekerjaannya. Seorang dengan tingkat kepuasan kerja yang tinggi menunjukkan sikap yang positif terhadap pekerjaannya.

Sedangkan seseorang yang tidak puas menunjukkan sikap negative. Herzberg menyatakan bahwa faktor yang mendatangkan kepuasan adalah prestasi, pengakuan, pekerjaan itu sendiri, tanggung jawab dan kemajuan (Armstrong dalam Ndraha, 2015). Nelson dan Quick (2016) kepuasan kerja adalah suatu kondisi emosional yang positif dan menyenangkan sebagai hasil dari penilaian pekerjan atau pengalaman pekerjaan seseorang. Menurut Kreitner dan Kinicki (2014) kepuasan kerja adalah suatu efektifitas atau respons emosional terhadap berbagai aspek pekerjaan. Dari pernyataan beberapa ahli di atas mengenai pengertian kepuasan kerja, peneliti dapat menyimpulkan bahwa kepuasan kerja merupakan sikap positif yang ditunjukkan oleh karyawan terhadap pekerjaannya, sehingga karyawan dapat bekerja dengan senang hati tanpa merasa terbebani dengan pekerjaan tersebut dan memberikan hasil yang optimal bagi perusahaan.

Menurut Goetsh dan Davis dalam Tjiptono (2015) kualitas merupakan suatu kondisi dinamis yang berhubungan dengan produk, jasa, manusia, proses, dan lingkungan yang memenuhi atau melebihi harapan. Krajewski dalam Sumadi (2015), kualitas dapat ditinjau dari sudut pandang produsen da konsumen. Ditinjau dari pandangan produsen kualitas adalah produk yang dalam produksinya telah sesuai dengan spesifikasinya atau standar yang dibuat oleh perusahaan.

Menurut Hardiyansyah (2017), bahwa pelayanan pada dasarnya adalah merupakan kegiatan atau manfaat yang ditawarkan oleh suatu pihak kepada pihak lain dan pada hakekatnya tidak berwujud serta tidak 
menghasilkan kepemilikan sesuatu, proses produksinya mungkin juga tidak dikaitkan dengan suatu produk fisik.

Menurut Surjadi (2016), pengertian umum pelayanan publik menurut Keputusan Menteri Pendayagunaan Aparatur Negara Nomor : 63 / KEP / M.PAN/7/2003 adalah segala kegiatan pelayanan yang dilaksanakan oleh penyelenggara pelayanan publik sebagai upaya pemenuhan kebutuhan penerima pelayanan maupun pelaksana ketentuan peraturan perundang-undangan. Dalam penyelenggaraan pelayanan publik dilakukan berdasarkan pada asas-asas umum kepemerintahan yang baik, meliputi : Kepastian hukum, Transparan, Daya tanggap, Berkeadilan, Efektif dan efisien, Tanggung jawab, Akuntanbilitas dan Tidak menyalahgunakan kewenangan.

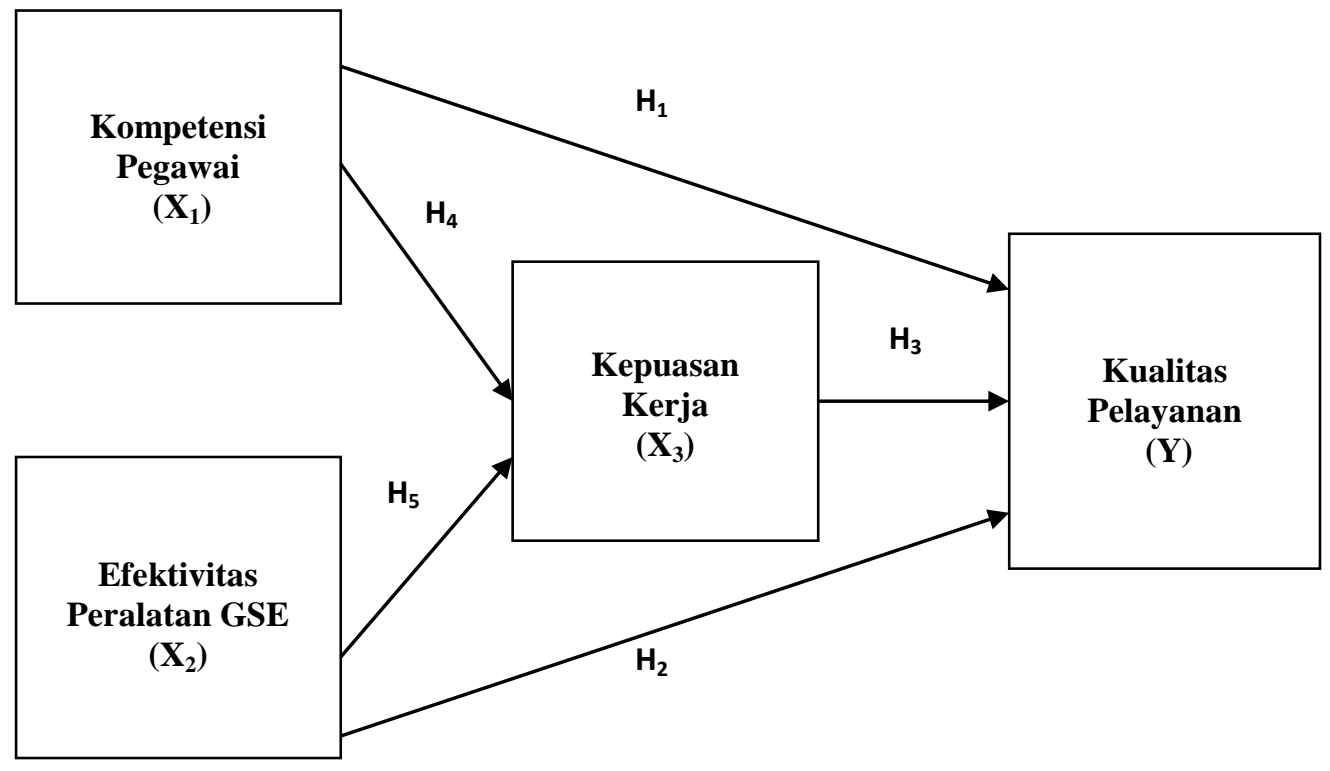

Gambar 1. Kerangka Berpikir

\section{METODE}

Penelitian ini dirancang dengan mengunakan metode deskriptif dengan pendekatan kuantitatif. Metode statistik deskriptif digunakan untuk menjelaskan fenomena yang terjadi perihal data penelitian. Sedangkan metode kuantitatif digunakan untuk menjelaskan pengaruh variabel bebas terhadap variabel terikat pada penelitian ini. Metode penelitian yang digunakan adalah metode survei dengan cara mengumpulkan data melalui instrumen penelitian, dan menyebarkan kuesioner kepada pelanggan yang hasilnya kemudian diolah melalui program SPSS_24.00 untuk mengetahui hubungan antar variabel yang ada. Metode tersebut digunakan untuk menguji hubungan antara dua variabel bebas dan satu terikat.

\section{HASIL DAN PEMBAHASAN}

Semua pertanyaan pada instrumen penelitian dalam penelitian ini adalah reliable, yang berarti pertanyaan dalam penelitian ini menghasilkan jawaban yang konsisten dari waktu ke waktu dan setiap pertanyaan tersebut dapat digunakan dalam penelitian ini. Pada uji Kolmogrov-Smirnov menunjukkan signifikansi seluruh variabel berada diatas batas $\alpha$ (standar eror) yakni sebesar 0,05 . Hasil menunjukkan secara keseluruhan setiap variable yaitu X1, X2, X3 dan Y hasil uji normalitas yaitu 0.549, 0.305, 0.787, 0.984 > 0,05 . Hal ini membuktikan bahwa data dari variable yang diteliti memiliki distribusi yang normal dan dapat dilanjutkan untuk pengujian asumsi klasik lainnya.

Tabel 2. Uji Parsial Variabel Kualitas Pelayanan

\begin{tabular}{|c|c|c|c|c|}
\hline & Coefficients $^{\mathrm{a}}$ & & & \\
\hline \multirow[t]{2}{*}{ Model } & $\begin{array}{l}\text { Unstandardized } \\
\text { Coefficients }\end{array}$ & $\begin{array}{c}\text { Standardized } \\
\text { Coefficients }\end{array}$ & \multirow[t]{2}{*}{$\mathrm{t}$} & \multirow[t]{2}{*}{ Sig. } \\
\hline & $\begin{array}{ll}\text { B } & \text { Std. Error }\end{array}$ & Beta & & \\
\hline
\end{tabular}




\begin{tabular}{lllrrrr}
\hline & (Constant) & .457 & 1.254 & & .364 & .718 \\
\cline { 2 - 7 } 1 & Kompetensi Pegawai & .262 & .050 & .191 & 5.207 & .000 \\
\cline { 2 - 7 } & Efektivitas Peralatan GSE & .248 & .034 & .136 & 5.428 & .002 \\
\cline { 2 - 7 } & Kepuasan Kerja & .489 & .035 & .804 & 19.942 & .000 \\
\hline \multicolumn{2}{l}{ a. Dependent Variable: Kualitas Pelayanan } \\
\multicolumn{6}{l}{ Sumber: Data olah Kuesioner (SPSS Versi 24.00) Tahun 2020 }
\end{tabular}

Berdasarkan tabel di atas dapat dilihat bahwa Uji t untuk menguji signifikansi setiap variabel independen, yaitu kompetensi pegawai, efektivitas peralatan GSE dan kepuasan kerja secara simultan (bersamasama) mempengaruhi kualitas pelayanan Bagian Operasi pada PT Jasa Angkasa Semesta Bandar Udara SoekarnoHatta Jakarta. Dalam hal ini, dasar pengambilan keputusan adalah dengan membandingkan t-tabel dengan thitung. Data di atas diketahui dk (derajat kebebasan) $=45-4=41$ dengan taraf kepercayaan $\alpha=0,05$ maka ttabel sebesar 1.682. Pedoman yang digunakan untuk menerima atau menolak hipotesis yaitu:

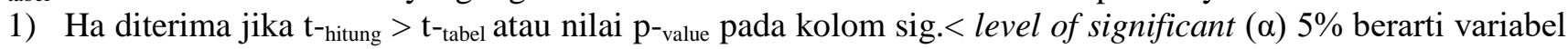
independen memiliki pengaruh terhadap variabel dependen.

2) Ho diterima jika $t_{- \text {hitung }}<\mathrm{t}_{\text {tabel }}$ atau nilai $\mathrm{p}$-value pada kolom sig. $>$ level of significant $(\alpha) 5 \%$ berarti variabel independen tidak memiliki pengaruh terhadap variabel dependen.

Berdasarkan hasil estimasi pada tabel sebelumnya maka berikut ini hasil uji t statistik dari masing-masing variabel independen sebagai berikut:

1) Kompetensi Pegawai

Hasil pengujian dengan menggunakan program SPSS_24.00 diperoleh nilai t statistik untuk kompetensi pegawai adalah 5.207 dan probabilitas 0.000 . Sedangkan nilai $t_{\text {tabel }}$ untuk jumlah observasi sebanyak 45 dengan tingkat signifikansi 5\% dan derajat kebebasan $(\mathrm{dk})=45-4=41$ diperoleh 1.682. Sehingga diperoleh bahwa t-statistik lebih besar dari ttabel atau $5.207>1.682$, dan juga dapat dilihat pada nilai probabilitas lebih kecil dari tingkat signifikansi $(\alpha) 5 \%$ atau $0.000<0,05$ maka dapat diambil kesimpulan bahwa label halal secara signifikan mempengaruhi kualitas pelayanan dengan kesimpulan H0 ditolak dan menerima Ha. Hal ini menyatakan bahwa kompetensi pegawai memberikan pengaruh nyata terhadap keputusan pembelian dengan tingkat kepercayaan $95 \%$ atau tingkat kesalahan $5 \%$. Nilai Beta pada variabel kompetensi pegawai sebesar 0.457 artinya $45.7 \%$ kompetensi pegawai mempengaruhi kualitas pelayanan, selebihnya dipengaruhi oleh faktor lain.

2) Efektivitas Peralatan GSE

a. Hasil pengujian dengan menggunakan program SPSS 24.00 diperoleh nilai t statistik untuk efektivitas peralatan GSE adalah 5.428 dan probabilitas 0.002. Sedangkan nilai t tabel untuk jumlah observasi sebanyak 45 dengan tingkat signifikansi $5 \%$ dan derajat kebebasan $(\mathrm{dk})=45-4=41$ diperoleh 1.682 . Sehingga diperoleh bahwa t-statistik lebih besar dari t tabel atau 5.428 $>1.682$, dan juga dapat dilihat pada nilai probabilitas lebih kecil dari tingkat signifikansi $(\alpha) 5 \%$ atau $0,001<0,05$ maka dapat diambil kesimpulan bahwa efektivitas peralatan GSE secara signifikan mempengaruhi kualitas pelayanan dengan kesimpulan H0 ditolak dan menerima Ha. Hal ini menyatakan bahwa efektivitas peralatan GSE memberikan pengaruh nyata terhadap kualitas pelayanan dengan tingkat kepercayaan 95\% atau tingkat kesalahan $5 \%$.

b. Nilai Beta pada variabel efektivitas peralatan GSE yaitu sebesar 0.248 artinya variabel efektivitas peralatan GSE memberikan pengaruh terhadap kualitas pelayanan sebesar 24.8\%. Selebihnya dipengaruhi oleh faktor lain yang tidak diteliti dalam penelitian ini. Hal ini didukung oleh penelitian yang dilakukan

3) Kepuasan Kerja

a. Hasil pengujian dengan menggunakan program SPSS_24.00 diperoleh nilai t statistik untuk kepuasan kerja adalah 19.942 dan probabilitas 0,000 . Sedangkan nilai $t_{\text {tabel }}$ untuk jumlah observasi sebanyak 45 dengan tingkat signifikansi 5\% dan derajat kebebasan $(\mathrm{dk})=45-4=41$ diperoleh 1.682 .

b. Sehingga diperoleh bahwa t-statistik lebih besar dari $t_{\text {tabel }}$ atau $19.942>1.682$, dan juga dapat dilihat pada nilai probabilitas lebih kecil dari tingkat signifikansi $(\alpha) 5 \%$ atau $0,000<0,05$ maka dapat 
diambil kesimpulan bahwa harga secara signifikan mempengaruhi kualitas pelayanan dengan kesimpulan HO ditolak dan menerima Ha. Hal ini menyatakan bahwa harga memberikan pengaruh nyata terhadap kualitas pelayanan dengan tingkat kepercayaan 95\% atau tingkat kesalahan 5\%.

Nilai Beta pada variabel kepuasan kerja yaitu sebesar 0.489 artinya variable kepuasan kerja memberikan kontribusi terhadap kualitas pelayanan sebesar $48.9 \%$. Selebihnya dipengaruhi oleh faktor lain yang tidak diteliti dalam penelitian ini.

\section{Analisis Tahap Dua}

Pada analisis tahap satu ini akan menguji efek moderasi dengan persamaan sebagai berikut :

$\mathrm{Y}=\mathrm{a}+\mathrm{b}_{1} \mathrm{X}_{1}+\mathrm{b}_{2} \mathrm{X}_{2}+\mathrm{e} 2$

a. $\quad$ Uji Determinasi Variabel Kepuasan Kerja

Tabel 3. Uji Determinasi Variabel Kepuasan Kerja

\begin{tabular}{|c|c|c|c|c|}
\hline & \multicolumn{4}{|c|}{ Model Summary } \\
\hline Model & $\mathrm{R}$ & R Square & $\begin{array}{l}\text { Adjusted R } \\
\text { Square }\end{array}$ & $\begin{array}{l}\text { Std. Error of the } \\
\text { Estimate }\end{array}$ \\
\hline 1 & $866^{\mathrm{a}}$ & .751 & .739 & 4.45169 \\
\hline \multicolumn{5}{|c|}{$\begin{array}{l}\text { a. Predictors: (Constant), Efektivitas Peralatan GSE, Kompetensi } \\
\text { Pegawai }\end{array}$} \\
\hline b. Depe & ent $\mathrm{Va}$ & ble: Kepua & Kerja & \\
\hline
\end{tabular}

Dari tabel di atas terlihat bahwa pada model regresi linier berganda untuk persamaan pertama, yaitu : Y $=\mathrm{a}+\mathrm{b}_{1} \mathrm{X}_{1}+\mathrm{b}_{2} \mathrm{X}_{2}+\mathrm{e} 2$ menunjukkan nilai koefisien determinasi sebesar 0.751 atau $75.1 \%$ yang memiliki arti bahwa kontribusi variabel kompetensi pegawai dan efektivitas peralatan GSE terhadap kepuasan kerja pelayanan Bagian Operasi pada PT Jasa Angkasa Semesta Bandar Udara Soekarno-Hatta Jakarta adalah sebesar $75.1 \%$ sedangkan sisanya $24.9 \%$ dipengaruhi oleh pengaruh faktor-faktor lain dari penelitian ini seperti motivasi, professional, kehandalan dan sebagainya.

b. Uji ANOVA Variabel Kepuasan Kerja

Tabel 4. Uji ANOVA Variabel Kepuasan Kerja

\begin{tabular}{llrrrr}
\hline Model & $\begin{array}{c}\text { Sum of } \\
\text { Squares }\end{array}$ & df & $\begin{array}{c}\text { Mean } \\
\text { Square }\end{array}$ & F & Sig. \\
\hline Regression & 2506.462 & 2 & 1253.231 & 63.238 & $.000^{\mathrm{b}}$ \\
\hline Residual & 832.338 & 42 & 19.818 & & \\
\hline Total & 3338.800 & 44 & & & \\
\hline a. Dependent Variable: Kepuasan Kerja & & \\
\hline $\begin{array}{l}\text { b. Predictors: (Constant), Efektivitas Peralatan GSE, } \\
\text { Kompetensi Pegawai }\end{array}$
\end{tabular}

Berdasarkan hasil pengujian di atas dapat dilihat nilai $\mathrm{F}_{\text {-hitung }}$ adalah 63.238 dengan nilai signifikansi adalah 0,000000. Nilai $\mathrm{F}_{\text {tabel }}$ untuk jumlah obeservasi sebanyak 45 dengan tingkat alpha 5\% dan $\mathrm{k}$ atau jumlah seluruh variabel baik variabel independen dan dependen adalah 4 , maka nilai $\mathrm{N} 1=\mathrm{k}-1=4-1=3, \mathrm{~N} 2=\mathrm{n}-\mathrm{k}$ $=45-4=41$ adalah 2.83. Sehingga diperoleh bahwa $\mathrm{F}_{\text {-hitung }}$ lebih besar dari $\mathrm{F}_{\text {-tabel }}$ atau $63.238>2.83$ dan juga dapat dilihat pada nilai probabilitas lebih kecil dari tingkat signifikansi $(\alpha) 5 \%$ atau $0,000000<0,05$ maka dapat diambil kesimpulan bahwa variabel kompetensi pegawai dan efektivitas peralatan GSE secara simultan (bersamasama) mempengaruhi kepuasan kerja Bagian Operasi pada PT Jasa Angkasa Semesta Bandar Udara Soekarno-Hatta Jakarta dengan kesimpulan Ho ditolak dan Ha diterima.

c Uji Parsial Variabel Kualitas Pelayanan 
Tabel 5.Uji Parsial Variabel Kualitas Pelayanan

\begin{tabular}{|c|c|c|c|c|c|c|}
\hline \multirow[t]{2}{*}{ Model } & & \multicolumn{2}{|c|}{$\begin{array}{l}\text { Unstandardized } \\
\text { Coefficients }\end{array}$} & \multirow{2}{*}{$\begin{array}{c}\begin{array}{c}\text { Standardized } \\
\text { Coefficients }\end{array} \\
\text { Beta }\end{array}$} & \multirow[t]{2}{*}{$\mathrm{t}$} & \multirow[t]{2}{*}{ Sig. } \\
\hline & & $\mathrm{B}$ & Std. Error & & & \\
\hline \multirow{3}{*}{1} & (Constant) & 4.630 & 3.473 & & 1.394 & .171 \\
\hline & Kompetensi Pegawai & .330 & .142 & .707 & 7.962 & .000 \\
\hline & Efektivitas Peralatan GSE & .406 & .138 & .261 & 3.945 & .005 \\
\hline a. Deper & ident Variable: Kepuasan Ke & & & & & \\
\hline
\end{tabular}

Berdasarkan tabel di atas dapat dilihat bahwa Uji t untuk menguji signifikansi setiap variabel independen, yaitu kompetensi pegawai dan efektivitas peralatan GSE secara simultan (bersamasama) mempengaruhi kepuasan kerja Bagian Operasi pada PT Jasa Angkasa Semesta Bandar Udara Soekarno-Hatta Jakarta. Dalam hal ini, dasar pengambilan keputusan adalah dengan membandingkan t-tabel dengan thitung. Data di atas diketahui dk (derajat kebebasan) $=45-4=41$ dengan taraf kepercayaan $\alpha=0,05$ maka t-tabel sebesar 1.682. Pedoman yang digunakan untuk menerima atau menolak hipotesis yaitu:

1) Ha diterima jika $t_{-h i t u n g}>t_{-t a b e l}$ atau nilai $p$-value pada kolom sig. $<$ level of significant $(\alpha) 5 \%$ berarti variabel independen memiliki pengaruh terhadap variabel dependen.

2) Ho diterima jika $t_{-{ }_{\text {hitung }}}<\mathrm{t}_{\text {tabel }}$ atau nilai $\mathrm{p}$-value pada kolom sig. $>$ level of significant $(\alpha) 5 \%$ berarti variabel independen tidak memiliki pengaruh terhadap variabel dependen.

Berdasarkan hasil estimasi pada tabel sebelumnya maka berikut ini hasil uji t statistik dari masing-masing variabel independen sebagai berikut:

1) Kompetensi Pegawai

Hasil pengujian dengan menggunakan program SPSS_24.00 diperoleh nilai t statistik untuk kompetensi pegawai adalah 7.962 dan probabilitas 0.000 . Sedangkan nilai $t_{\text {tabel }}$ untuk jumlah observasi sebanyak 45 dengan tingkat signifikansi $5 \%$ dan derajat kebebasan $(\mathrm{dk})=45-4=41$ diperoleh 1.682. Sehingga diperoleh bahwa t-statistik lebih besar dari $\mathrm{t}_{\text {tabel }}$ atau $7.962>1.682$, dan juga dapat dilihat pada nilai probabilitas lebih kecil dari tingkat signifikansi $(\alpha) 5 \%$ atau $0.000<0,05$ maka dapat diambil kesimpulan bahwa label halal secara signifikan mempengaruhi kualitas pelayanan dengan kesimpulan H0 ditolak dan menerima $\mathrm{Ha}$. Hal ini menyatakan bahwa kompetensi pegawai memberikan pengaruh nyata terhadap keputusan pembelian dengan tingkat kepercayaan 95\% atau tingkat kesalahan 5\%. Nilai Beta pada variabel kompetensi pegawai sebesar 0.330 artinya $23.0 \%$ kompetensi pegawai mempengaruhi kualitas pelayanan, selebihnya dipengaruhi oleh faktor lain.

2) Efektivitas Peralatan GSE

Hasil pengujian dengan menggunakan program SPSS 24.00 diperoleh nilai t statistik untuk efektivitas peralatan GSE adalah 3.945 dan probabilitas 0.002. Sedangkan nilai $t_{\text {tabel }}$ untuk jumlah observasi sebanyak 45 dengan tingkat signifikansi 5\% dan derajat kebebasan $(\mathrm{dk})=45-4=41$ diperoleh 1.682. Sehingga diperoleh bahwa t-statistik lebih besar dari $\mathrm{t}_{\text {tabel }} \mathrm{l}$ atau $3.945>1.682$, dan juga dapat dilihat pada nilai probabilitas lebih kecil dari tingkat signifikansi $(\alpha) 5 \%$ atau $0,001<0,05$ maka dapat diambil kesimpulan bahwa efektivitas peralatan GSE secara signifikan mempengaruhi kualitas pelayanan dengan kesimpulan H0 ditolak dan menerima Ha. Hal ini menyatakan bahwa efektivitas peralatan GSE memberikan pengaruh nyata terhadap kualitas pelayanan dengan tingkat kepercayaan 95\% atau tingkat kesalahan 5\%. Nilai Beta pada variabel efektivitas peralatan GSE yaitu sebesar 0.406 artinya variabel efektivitas peralatan GSE memberikan pengaruh terhadap kualitas pelayanan sebesar $40.6 \%$. Selebihnya dipengaruhi oleh faktor lain yang tidak diteliti dalam penelitian ini. Hal ini didukung oleh penelitian yang dilakukan.

Tabel 6. Hasil Uji Signifikansi Pengaruh Langsung dan Tidak Langsung

\begin{tabular}{cccccc}
\hline $\begin{array}{c}\text { Inderect } \\
\text { Effect }\end{array}$ & $\begin{array}{c}\text { Koefisien } \\
\text { Jalur (pij) }\end{array}$ & $\begin{array}{c}\text { Kesalahan } \\
\text { Baku } \\
(\mathbf{s b i})\end{array}$ & $\mathbf{Z}_{\text {hitung }}$ & $\mathbf{t}_{\text {hitung }}$ & Simpulan \\
\hline $\mathrm{X}_{1}$ terhadap Y melalui $\mathrm{X}_{3}$ & 0.262 & 0.050 & 2.257 & 1.682 & Signifikan \\
\hline $\mathrm{X}_{2}$ terhadap Y melalui $\mathrm{X}_{3}$ & 0.248 & 0.034 & 28.804 & 1.682 & Signifikan \\
\hline
\end{tabular}


1. Analisis Tahap I $\left(Y=a+b_{1} X_{1}+b_{2} X_{2}+b_{3} X_{3}+e 1\right)$

a. Pengaruh Kompetensi Pegawai terhadap Kualitas Pelayanan

Berdasarkan hasil penelitian bahwa pengaruh kompetensi pegawai terhadap kualitas pelayanan Bagian Operasional PT. Jasa Angkasa Semesta di Bandar Udara Soekarno-Hatta Jakarta sebesar 0.262 dengan standar error 0.000 dan pengaruhnya signifikan dengan nilai $t_{\text {hitung }} 5.207$ lebih besar dibandingkan dengan $\mathrm{t}_{\text {tabel }}$, maka $\mathrm{H}_{0}$ ditolak dan $\mathrm{H}_{1}$ diterima, artinya terdapat pengaruh antara kompetensi pegawai dengan kualitas pelayanan Bagian Operasi pada PT Jasa Angkasa Semesta Bandar Udara SoekarnoHatta Jakarta.

b. Pengaruh Efektivitas Peralatan GSE terhadap Kualitas Pelayanan

Berdasarkan hasil penelitian bahwa efektivitas peralatan GSE terhadap kualitas pelayanan Bagian Operasional PT. Jasa Angkasa Semesta di Bandar Udara Soekarno-Hatta Jakarta sebesar 0.248 dengan standar error 0.002 dan pengaruhnya signifikan dengan nilai $t_{\text {hitung }} 5.428$ lebih besar dibandingkan dengan $\mathrm{t}_{\text {tabel }}$, maka $\mathrm{H}_{0}$ ditolak dan $\mathrm{H}_{1}$ diterima, artinya terdapat pengaruh antara efektivitas peralatan GSE terhadap kualitas pelayanan Bagian Operasional PT. Jasa Angkasa Semesta di Bandar Udara Soekarno-Hatta Jakarta.

c. Pengaruh Kepuasan Kerja terhadap Kualitas Pelayanan

Berdasarkan hasil penelitian bahwa pengaruh kepuasan kerja terhadap kualitas pelayanan Bagian Operasional PT. Jasa Angkasa Semesta di Bandar Udara Soekarno-Hatta Jakarta sebesar 0.489 dengan standar error 0.000 dan pengaruhnya signifikan dengan nilai $t_{\text {hitung }} 19.942$ lebih besar dibandingkan dengan $t_{\text {tabel }}$, maka $\mathrm{H}_{0}$ ditolak dan $\mathrm{H}_{1}$ diterima, artinya terdapat pengaruh kepuasan kerja terhadap kualitas pelayanan Bagian Operasional PT. Jasa Angkasa Semesta di Bandar Udara Soekarno-Hatta Jakarta.

Dari keterangan diatas pengaruh langsung antara variabel kompetensi pegawai, efektivitas peralatan GSE dan kepuasan kerja terhadap kualitas pelayanan diatas dapat disimpulkan bahwa kualitas pelayanan Bagian Operasional PT. Jasa Angkasa Semesta di Bandar Udara Soekarno-Hatta Jakarta, memiliki urutan yaitu kepuasan kerja sebesar 0.489 atau 48.9\%, kompetensi pegawai 0.262 atau $26.2 \%$ dan efektivitas peralatan GSES sebesar 0.262 atau 26.2\%. Hasil penelitian bahwa ketika kualitas pelayanan pegawai dapat dilihat pertama karena kepuasan kerja, kedua dapat dilihat kompetensi pegawai yang handal dalam mengerjakan tugasnya dan ketiga dengan melihat efektivitas peralatan GSE dalam memberikan pelayanan pada pesawat, penumpang dan barang.

\section{Analisis Tahap II}

a. Pengaruh Kompetensi Pegawai terhadap Kualitas Pelayanan Melalui Kepuasan Kerja

Berdasarkan hasil penelitian bahwa pengaruh tidak langsung kompetensi pegawai terhadap kualitas pelayanan Bagian Operasional PT. Jasa Angkasa Semesta di Bandar Udara Soekarno-Hatta Jakarta melalui kepuasan kerja adalah sebesar 0.330 dengan standar error 0.000 dan pengaruhnya signifikan dengan nilai $\mathrm{t}_{\text {hitung }} 2.257$, lebih besar dibandingkan dengan nilai $\mathrm{t}_{\text {tabel }} 1.682$, maka $\mathrm{H}_{0}$ ditolak dan $\mathrm{H}_{4}$ diterima, artinya terdapat pengaruh tidak langsung kompetensi pegawai terhadap kualitas pelayanan melalui kepuasan kerja.

b. Pengaruh Efektivitas Peralatan GSE terhadap Kualitas Pelayanan Melalui Kepuasan Kerja

Berdasarkan hasil penelitian bahwa pengaruh tidak langsung efektivitas peralatan GSE terhadap kualitas pelayanan melalui kepuasan kerja adalah sebesar 0.248 dan pengaruhnya signifikan dengan nilai $t_{\text {hitung }} 28.804$, lebih besar dibandingkan dengan nilai $\mathrm{t}_{\text {tabel }} 1.682$, maka $\mathrm{H} 0$ ditolak dan $\mathrm{H}_{5}$ diterima, artinya terdapat pengaruh tidak langsung efektivitas peralatan GSE terhadap kualitas pelayanan melalui kepuasan kerja.

Dari keterangan diatas pengaruh tidak langsung variabel kompetensi pegawai terhadap kualitas pelayanan melalui kepuasan kerja dan variabel efektivitas peralatan GSE terhadap kualitas pelayanan melalui kepuasan kerja dapat disimpulkan bahwa kompetensi pegawai memberikan kontribusi terhadap kepuasan kerja disebabkan oleh kemampuan-kemampuan yang dimiliki pegawai dalam menyelesaikan pekerjaan karena mampu memenuhi target dan tujuan perusahaan yang telah ditentukan. kepuasan tersendiri oleh para pegawai. Sehingga semua penggunaan peralatan GSE dapat digunakan secara efektif dan efisien waktu dalam meningkatkan kualitas pelayanan Bagian Operasi pada PT Jasa Angkasa Semesta Bandar Udara Soekarno-Hatta Jakarta. 


\section{KESIMPLAN DAN SARAN}

Pengaruh langsung kompetensi pegawai, efektivitas peralatan GSE dan kepuasan kerja terhadap kualitas pelayanan sebagai berikut: Secara regresi pengaruh kompetensi pegawai terhadap kualitas pelayanan sebesar 0.262 dengan standar error 0.000 dan pengaruhnya signifikan dengan nilai $t_{\text {hitung }} 5.207$ lebih besar dibandingkan dengan $\mathrm{t}_{\text {tabel}}$, maka $\mathrm{H}_{0}$ ditolak dan $\mathrm{H}_{1}$ diterima, artinya terdapat pengaruh antara kompetensi pegawai dengan kualitas pelayanan, untuk efektivitas peralatan GSE terhadap kualitas pelayanan sebesar 0.248 dan pengaruhnya signifikan dengan nilai $\mathrm{t}_{\text {hitung }} 5.428$ lebih besar dibandingkan dengan $\mathrm{t}_{\text {tabel }}$, maka $\mathrm{H}_{0}$ ditolak dan $\mathrm{H}_{1}$ diterima, artinya terdapat pengaruh antara efektivitas peralatan GSE terhadap kualitas pelayanan Bagian Operasional PT. Jasa Angkasa Semesta di Bandar Udara Soekarno-Hatta Jakarta, sedangkan pengaruh kepuasan kerja terhadap kualitas pelayanan sebesar 0.489 dengan standar error 0.000 dan pengaruhnya signifikan dengan nilai $t_{\text {hitung }} 19.942$ lebih besar dibandingkan dengan $t_{\text {tabel }}$, maka $\mathrm{H}_{0}$ ditolak dan $\mathrm{H}_{1}$ diterima, artinya terdapat pengaruh kepuasan kerja terhadap kualitas pelayanan Bagian Operasional PT. Jasa Angkasa Semesta di Bandar Udara Soekarno-Hatta Jakarta. Untuk pengaruh langsung antara variabel kompetensi pegawai, efektivitas peralatan GSE dan kepuasan kerja terhadap kualitas pelayanan diatas dapat disimpulkan bahwa kualitas pelayanan Bagian Operasional PT. Jasa Angkasa Semesta di Bandar Udara Soekarno-Hatta Jakarta, memiliki urutan yaitu kepuasan kerja sebesar 0.489 atau $48.9 \%$, kompetensi pegawai 0.262 atau $26.2 \%$ dan efektivitas peralatan GSES sebesar 0.262 atau $26.2 \%$.

Pengaruh tidak langsung kompetensi pegawai dan efektivitas peralatan GSE terhadap kualitas pelayanan melalui kepuaasan kerja adalah sebagai berikut: Pengaruh tidak langsung kompetensi pegawai terhadap kualitas pelayanan Bagian Operasional PT. Jasa Angkasa Semesta di Bandar Udara Soekarno-Hatta Jakarta melalui kepuasan kerja adalah sebesar 0.330 dengan standar error 0.000 dan pengaruhnya signifikan dengan nilai $\mathrm{t}_{\text {hitung }} 2.257$, lebih besar dibandingkan dengan nilai $\mathrm{t}_{\text {tabel }} 1.682$, maka $\mathrm{H}_{0}$ ditolak dan $\mathrm{H}_{4}$ diterima, artinya terdapat pengaruh tidak langsung kompetensi pegawai terhadap kualitas pelayanan melalui kepuasan kerja, sedangkan pengaruh tidak langsung efektivitas peralatan GSE terhadap kualitas pelayanan melalui kepuasan kerja adalah sebesar 0.248 dan pengaruhnya signifikan dengan nilai $t_{\text {hitung }} 28.804$, lebih besar dibandingkan dengan nilai $\mathrm{t}_{\text {tabel }} 1.682$, maka $\mathrm{HO}$ ditolak dan $\mathrm{H}_{5}$ diterima, artinya terdapat pengaruh tidak langsung efektivitas peralatan GSE terhadap kualitas pelayanan melalui kepuasan kerja, sedangkan pengaruh tidak langsung variabel kompetensi pegawai terhadap kualitas pelayanan melalui kepuasan kerja dan variabel efektivitas peralatan GSE terhadap kualitas pelayanan melalui kepuasan kerja dapat disimpulkan bahwa kompetensi pegawai memberikan kontribusi terhadap kepuasan kerja disebabkan oleh kemampuan-kemampuan yang dimiliki pegawai dalam menyelesaikan pekerjaan karena mampu memenuhi target dan tujuan perusahaan yang telah ditentukan. kepuasan tersendiri oleh para pegawai. 


\section{Daftar Pustaka}

\section{Buku}

Amstrong, Michael. 2016. Manajemen Sumber Daya Manusia. PT Elexmedia Komputindo. Jakarta

Arikunto, S. (2015). Prosedur Penelitian: Suatu Pendekatan Praktek. Jakarta: PT. Rineka Cipta

Arifin, Z. (2011). Penenlitian Pendidikan Metode dan Paradigma Baru. Bandung: Remaja Rosda Kary

Bustami. (2011). Penjaminan Mutu Pelayanan Pelanggan \& Akseptabilitasnya. Jakarta: Erlangga.

Davis, Gordon B. (2014) Kerangka Dasar Sistem Informasi Manajemen. Palembang: Maxikom

Damodar N., Gujarati dan Dawn C. Porter. (2012). Dasar-dasar Ekonometrika Buku 2. Edisi 5. Raden Carlos Mangunsong (penj.). Jakarta: Salemba Empat

Dunnette. (2012). Ketrampilan SDM, Kencana Prenada Media Group : Jakarta

Gibson, et al. (2016). Organizational: Behavior, Structure, Processes. New York: The McGraw Hill Companies, Inc.

Handoko, T. H. (2015). Manajemen Edisi 2. Yogyakarta: BPFE

Hardiansyah, 2011 Kualitas Pelayanan Publik: Konsep, Dimensi, Indikator dan Implementasinya. Yogyakarta : Gava Media.

Hair et al. (210). Multivariate Data Analysis, Seventh Edition. Pearson Prentice Hall, 2010

Hari Lubis dan Martini Husein (2014), Teori Orgnisasi, Jakarta, Pusat Antar Ilmu-ilmu Sosial

Hutapea, Parulian dan Nurianna Thoha (2017). Kompetensi komunikasi Plus : Teori, Desain, Kasus dan Penerapan untuk HR dan Organisasi yang Dinamis, Penerbit : Gramedia Pustaka Utama, Jakarta

Irianto, J. (2011). Manajemen Sumber Daya Manusia. Surabaya : Insan Cendekia

Iverson. (2014). Memahami Keterampilan Pribadi. CV. Pustaka : Bandung

Luthans, Fred (2011). Perilaku organisasi. Yogayakarta : Andi

Lovelock, Christopher H dan Lauren K. Wright, (2007), Manajemen Pemasaran Jasa, Alih bahasa Agus Widyantoro, Cetakan Kedua, Jakarta; PT. INDEKS.

Masruri (2014). Analisis Efektifitas Program Nasional Pemberdayaan Masyarakat Mandiri Perkotaan. Padang: Akademia Permata.

Moeheriono. 2017. Pengukuran Kinerja Berbasis Kompetensi. Jakarta: Raja, Grafindo Persada

Nadler, Leonard, (2012). Designing Training Programs : The Critical Events Models, USA, Wesley Publishing Company.

Priyatno, Duwi. (2012). Cara Kilat Belajar Analisis Data dengan SPSS 20 . Yogyakarta: Andi Offset.

Riduwan. (2015). Metode dan Teknik Menyusun Tesisi, Bandung. Alfabeta

Robbins, P.Stephen. (2015). Perilaku Organisasi. Salemba Empat. Jakarta

Robbins, P.Stephen dan Timothy A. Judge. 2015. Perilaku Organisasi. Salemba Empat. Jakarta

Rangkuti, F (2014). Measuring Custumer Satisfaction : Teknik Mengukur dan Strategi Meningkatkan Kepuasan Pelanggan, PT. Gramedia Pustaka Utama, Jakarta

Rais dan Saembodo. (2016). Manajemen Sumber Daya Manusia. Malang: Universitas Muhammadiyah Malang.

Sekaran, Uma \& Roger Bougie. (2016). Research Methods for Business - A Skill Building Approach, 5th Edition, United Kingdom : John Wiley \& Son Ltd

Sumadi, S (2015). Metodologi Penelitian, Jakarta: PT. Raja Grafindo Persada Media.

Sutrisno, E. (2015). Manajemen Sumber Daya Manusia. Cetakan Keenam. Pranada Media Group, Jakarta

Surjadi. (2012). Pengembangan Kinerja Pelayanan Publik. Bandung: PT Refika Aditama.

Sugiyono. (2016). Metode Penelitian Bisnis. Bandung : Alfabetha.

Steers Richard. M. (2015). Efektivitas Organisasi. (Terjemahan). Jakarta: Erlangga

Tjiptono, F. (2015). Service Managemen Mewujutkan Layanan Prima; Andi Yogyakarta,

Ulber, Silalahi. (2012). Metode Penelitian Sosial. Bandung : PT. Refika Aditama.

Veithzal Rivai, M.B.A \& Ella Jauvani Sagala (2015). Manajemen Sumber Daya Manusia untuk Perusahaan. Edisi Ketiga. Jakarta : Penerbit PT. Raja Grafindo Persada

Wahyudi, B (2012), Manajemen Sumber Daya Manusia. Jakarta : Sulita

\section{Peraturan dan Perundang-undangan}

Instruksi Presiden Nomor I/ 1995 tentang Peningkatan Kualitas Aparatur Pemerintahan Kepada Masyarakat IATA Airport Handling Manual, 810 Annex A, Tahun 2004 
Airport Handling Manual (AHM 810) tentang IATA Standard Ground handling Agreement, Annex A Ground handling Service, Section 4, Sub Section 4 (Ref AHM 18 Tahun 1998

Keputusan Menteri Pendayagunaan Aparatur Negara Nomor 63 Tahun 2003, tentang Pedoman Umum Penyelenggaraan Pelayanan Publik

Peraturan Menteri Dalam Negeri Nomor 6 tahun 2007 tentang Petunjuk Teknis Penyusunan dan Penetapan Standar Pelayanan

Peraturan Pemerintah Nomor 65 tahun 2005, tentang Pedoman Penyusunan dan Penerapan SPM.

Wibowo . 2016 . Manajemen Kinerja. Edisi Keempat . Jakarta : Rajawali Pers.

\section{Jurnal}

Andri, Roswan Kasim dan Endang Wahyuni (2016) Jasa Pelayanan Bandara Halim Perdana Kusuma dan Bandara Husein Sastranegara Jurnal Manajemen Transportasi \& Logistik (JMTranslog) - Vol. 03 No. 1, Maret 2016

Arlina Nurbaity Lubis dan Martin. Pengaruh Harga dan Kualitas Pelayanan terhadap Kepuasan Penumpang Lion Air Rute Medan - Jakarta, Universitas Sumatera Utara, Januari 2014: 21-24

Gunawan (2014) Analisis Kualitas Pelayanan Penumpang Pesawat Udara Dengan Menggunakan Metode QFD Jurnal Transportasi

Hashim, J. dan Wok, S. 2015. Competence, Performance, and Trainability ofOlder Workers of Higher Educational Institution in Malaysia. Journal of Employee Relations.Vol. 36 Iss 1 pp. 82-106.

Herdanu Sri Novanto (2010) Kualitas Pelayanan : Faktor-Faktor Yang Mempengaruhi Dan Dampaknya Pada Nilai Pelanggan (Studi Pada PT. Angkasa Pura I (Persero) Kantor Cabang Bandara Ahmad Yani Semarang) Jurnal Bisnis STRATEGI Vol. 19 No. 1 Juli 2010.

Parasuraman, A., Berry, L.L., and Zeithaml, A.V., (1988), "SERVQUAL: A Multiple Item Scale for Measuring Consumer Perceptions of Service Quality”, Journal of Retailing, Vol. 64, No. 1, Spring, 12-40.

Oshan. M. Kothadiya (2016), Providing Good Service Quality And Customer Satisfaction For Airline Ground Services Master of Science Student in Management of Technology, Delft University of Technology, Netherlands, Journal of Tecnnology) Volume 4, Issue 8, August 2016, PP 43-56

Ridha Kurniawan, (2017).Passengers Perspective toward Airport Service Quality (ASQ) (Case Study at Soekarno-Hatta International Airport) oleh, Karlstad University, Karlstad, SWEDEN, Journal of the Civil Engineering Forum, Vol. 3 No. 1 (January 2017).

Tran Phi Hoang1, Dang Minh Thu1, Nguyen Thu Ha1, Huynh Kim Quy (2016), Factors Affecting The Service Quality Standards at Theinternational Airports When Viet Nam Integrates TPP: A Study at Tan Son Nhat Airport, Ho Chi Minh City, Vietnam Industrial University of Ho Chi Minh City, Vietnam, British Journal of Marketing Studies Vol.4, No.1, pp.43-52, February 2016.

Wibawa. 2014. Pengaruh Kualitas Pelayanan, Harga dan Promosi Terhadap Loyalitas Pelanggan Melalui Kepuasan Pelanggan. Jurnal Ilmu Administrasi Bisnis V1 3 No 4.

\section{Website :}

www.bps.go.id, diakses 18 Juni 2019 pukul. 20.30 WIB

http://ebagazalba.blogspot.co.id/2013/05/mengenal-ground-support-equipment-gse.html 